\title{
Effect of Waste Dumps on Groundwater in Choba using Geophysical Method
}

\author{
UGWU, S. A.; NWOSU, J. I. \\ Department of Geology \\ Faculty of Sciences \\ University of Port Harcourt \\ E-mail: ugwusa@yahoo.com.Phone08037441914
}

\begin{abstract}
The aim of this work is to investigate the effect of waste dumps on the groundwater in Choba using resistivity sounding method and laboratory water sample analysis. An ABEM SAS 1000 terrameter was used to acquire data in two locations namely; at the dumpsite and at University Demonstration Secondary School adjudged to be free from dumps which served as a control. The result of the survey interpreted by 1P12 win and offix softwares shows two characteristic curve types: - Type A curve at the dumpsite and Type $\mathrm{H}$ curve at the University Demonstration Secondary School. The result further indicates that the first two layers at the dumpsite has resistivities of 59.91 and $20.10 \mathrm{ohm} . \mathrm{m}$ respectively and at the Demonstration Secondary school as 173.00 and $512.00 \mathrm{ohm} . \mathrm{m}$ respectively, showing that the groundwater at the dumpsite is polluted because of the high conductivity. This was confirmed by the laboratory water sample analysis from the environ. However, fresh uncontaminated water is got below $23 \mathrm{~m}$ deep at the two sites. Niger Delta has multi aquifer systems, therefore geophysical survey is essential to locate at least the depth to the third aquifer which hopefully will give portable drinking water free of contamination. (a) JASEM
\end{abstract}

Choba community is located along the East-West road and lies between latitudes $4^{0} 31^{\prime}$ and $5^{\circ} 00^{\prime} \mathrm{N}$ and longitudes $6^{0} 45^{\prime}$ and $7^{0} 30^{\prime} \mathrm{E}$ in the South South Nigeria. Some component of these wastes including food, paper etc consume oxygen thereby changing the redox potential of the liquid present. Percolating groundwater provides a medium through which wastes particularly organics can undergo degradation into simpler substances through biochemical reactions involving dissolution, hydrolysis, oxidation and reduction processes. This leachate, the liquid drains from the dump, mainly organic carbon largely in the form of fulvic acids (Taylor and Allen, 2001) migrate downward and contaminate the groundwater. Each year about two million people die as a result of poor sanitation and contaminated water, ninety percent $(90 \%)$ of the victims are children (Anon, 2009).

Various workers have studied the effect of solid wastes on the groundwater in Port Harcourt and its environs. Udom and Esu (2004) carried out a preliminary assessment of the impact of solid wastes on soil and groundwater in Port Harcourt city and it's environ and concluded that the groundwater is contaminated. Udom et al (1999) studied the Hydrogeochemistry of groundwater in part of Port Harcourt and Tai Eleme Local Government Areas and discovered that the groundwater in the Benin Formation is soft and low in dissolved constituents except $\mathrm{pH}$ and iron with mean values of $6.01 \mathrm{mg} / \mathrm{l}$ and $0.36 \mathrm{mg} / \mathrm{l}$ respectively. Akpokodje (1999) noted that a staggering amount of solid waste is generated in the Port Harcourt metropolis each year.

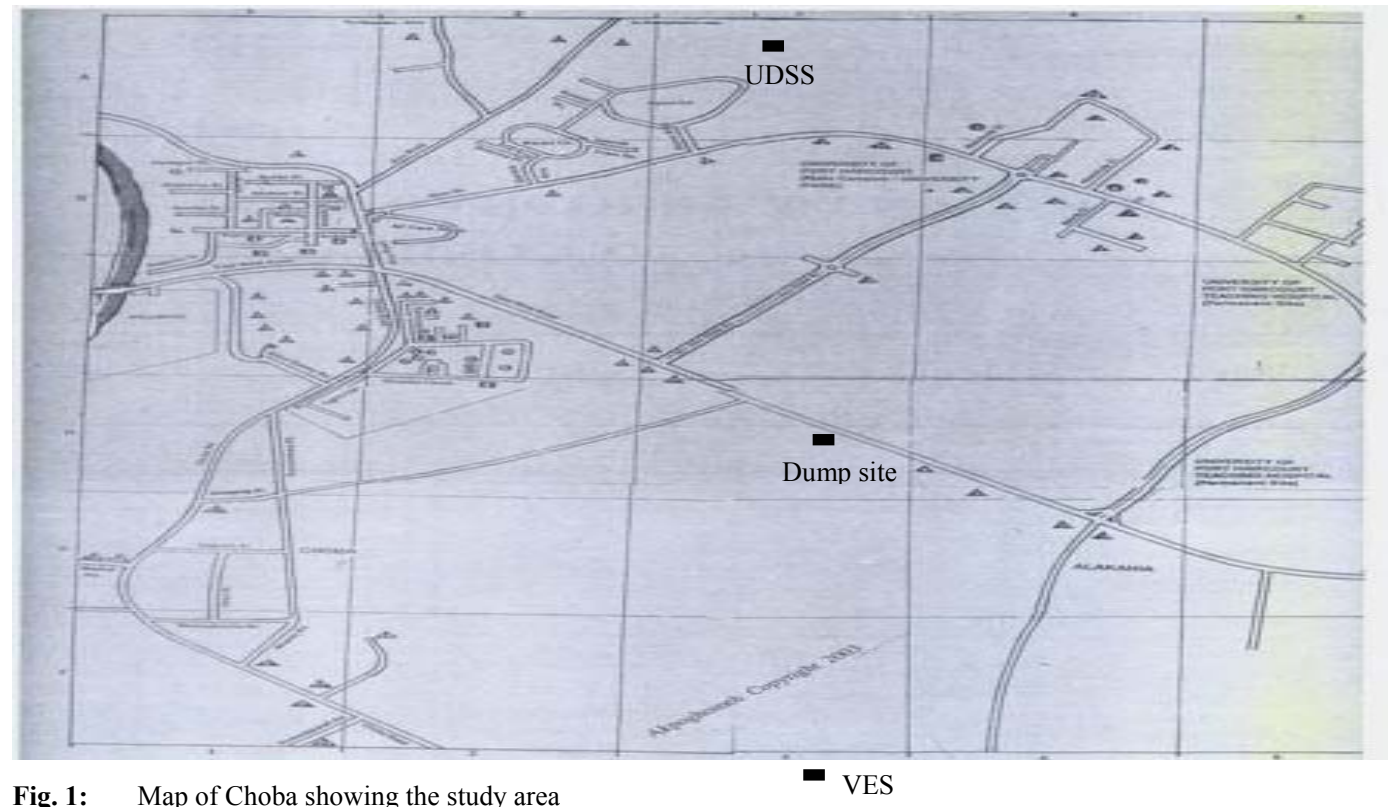

Fig. 1: Map of Choba showing the study area

* Corresponding author: Ugwu, S. A 
Although there are various geophysical techniques that are commonly employed in groundwater investigation in coastal environment, however, electrical resistivity methods are the most unique because of their ability to detect increases in porewater conductivity (Abdul Nassir et al 2000, Adepelumi et al, 2008). Electrical resistivity was chosen for this work based on interesting results obtained by previous workers like Barker (1990) and Williams et al (1990) that confirmed the detection of contaminated substrate of sandstone using Schlumberger resistivity sounding in Yorkshire in UK and Novo in Brazil respectively.

The thrust of this research is to investigate the effect of municipal and other solid waste dumps on the groundwater system in this University town of Choba using geophysical techniques which will be aided by laboratory water analysis sampled within the area. This became necessary as the inhabitants of this town depend mostly on groundwater for their daily water demands.

\section{GEOLOGY}

The development of the Niger Delta can be best described in six stages. The development of the modern Niger Delta began at the Fourth stage in the early Tertiary when the dominant process was regressive. The regressive phase continued into stage five, in the later Tertiary when the Delta became well developed. Stage six portrays the present day Delta which is continuing to prograde. The Niger Delta was limited along the northwest-by the Benin Flank, which is the subsurface continuation of the West African shield. The eastern edge was limited by the Calabar Flank, the subsurface continuation of the Oban massive. The Abakaliki and Onitsha uplifts, the Benue trough and the Afikpo Syncline boarder the Niger Delta on the northern limit. Although the delta basin appears to be open to the south, there are some data suggesting that a positive basement feature occurs at depth beneath the southern end (Merki. 1972, Murat, 1972). It covers an area of about 75,000 square kilometers (Efu-Efetor, 1997). Rivers Benue and Niger supplied sediments to the basin while minor amount of sediment was contributed by the Cross River until Oligocene time (Short and Stauble, 1967). The three lithologic Formations of the modern
Niger Delta (Benin, Agbada and Akata) consist primarily of regressive Tertiary age sediments. These formations transgress time boundaries, becoming progressively younger in a downdip direction ranging in age from Oligo- Miocene to Recent (Helm and Searly, 1978). The Benin Formation consists of freshwater, continental (fluviatile) sands and gravels, with occasional interbeded shales towards the base. The sands are coarse grained to very fine grained and are poorly sorted. They are primarily non-marine to paralic: the Benin Formation constitutes the major aquiferous layer in the study are (Efu-Efetor, 1997, Udom and Esu, 2004).

\section{DATA ACQUISITION AND PROCESSING}

Two (2) Vertical Electrical Sounding (VES) data were acquired at two (2) designated points namely, old dumpsite near Total Filling Station along the East-West road Choba and the University Demonstration Secondary School (UDSS), adjudged to be free from dumpsite and leachates which serves as a control. The two areas are separated by a distance of about $3000 \mathrm{~m}$. An ABEM SAS 1000 terrameter was used for the resistivity measurements using the popular Schlumberger electrode configuration. The field resistivity data was interpreted using the 1-Dimension inversion programs; 1P12 win and Offix softwares. Typical resistivity sounding curves obtained after the inversion are shown in figures 2 and 3.

\section{DISCUSSION OF RESULTS}

Two (2) Vertical Electrical Soundings were traversed at Choba, one at the Eastern end of the Total Filling Station along the East-West road i.e. the position of the dumpsite and the other at the University Demonstration Secondary School field. The second station was free from dumpsite and served as a control (Fig. 1). The interpretation of the sounding curves shows two characteristic curve types namely; type A curve at the dumpsite (Fig. 2) and Type H curve (Fig. 3) at the University Demonstration Secondary School (UDSS) respectively. The model descriptions of the two sites are presented as table 1 .

Table 1: Comparison of Geoelectrical Soundings at the Dumpsite and UDSS DUMPSITE UDSS

\begin{tabular}{|c|c|c|c|c|c|c|c|}
\hline $\begin{array}{l}\text { Layer } \\
\text { (m) }\end{array}$ & $\rho(\Omega m)$ & Depth (m) & Thickness (m) & Layer (m) & $\rho(\Omega m)$ & Depth (m) & Thickness (m) \\
\hline 1 & 59.91 & 0.51 & 0.51 & 1 & 1731.00 & 2.94 & 2.94 \\
\hline 2 & 20.10 & 10.00 & 9.49 & 2 & 512.00 & 12.30 & 9.36 \\
\hline 3 & 3298.10 & 22.00 & 12.00 & 3 & 2715.13 & 23.30 & 11.00 \\
\hline 4 & 812.00 & 23.07 & 1.70 & 4 & 490 & - & - \\
\hline 5 & 677.08 & - & - & & & & \\
\hline Rms & error $=1.06$ & & & Rms & error $=1 . i$ & & \\
\hline
\end{tabular}


From the model (Table 1), the low resistivity value of $20.10 \mathrm{ohm} . \mathrm{m}$ at the dumpsite is an indicative of pollution in layer two Reynolds, (1997). The leachates from the open dumps usually contain biological and chemical constituents. Organic matter decomposing under aerobic conditions produces carbon dioxide which reacts with the leaching water to form carbonic acid.

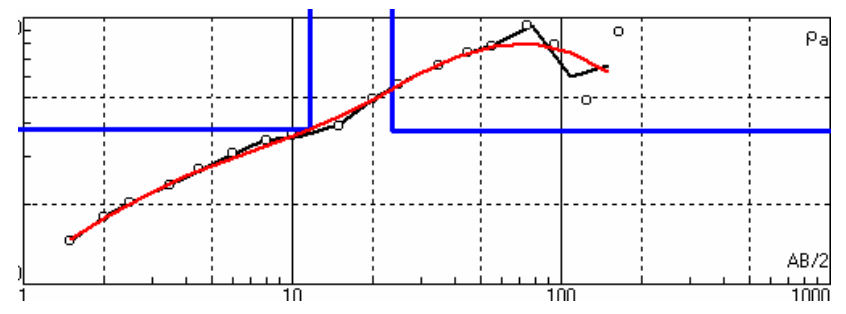

Fig. 2 Type A curve at the dump site

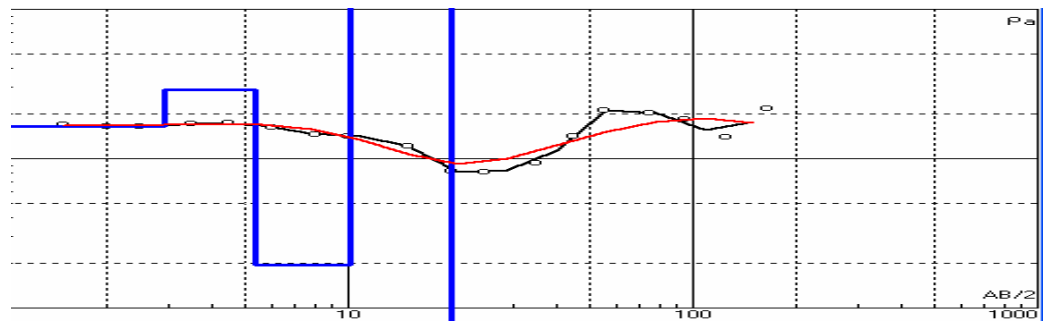

Fig. 3 Type H curve at UDSS

$\mathrm{CO}_{2}+\mathrm{H}_{2} \mathrm{O} \longrightarrow \mathrm{H}_{2} \mathrm{CO}_{3}$. This in turn acts upon metals in the refuse and other calcareous material in the soils and rocks resulting in increasing hardness and conductivity of contaminated water (Schneider, 1978). This is followed by the third layer with a high resistivity value of $3298.10 \mathrm{ohm} . \mathrm{m}$ at a depth of $22.00 \mathrm{~m}$ suspected to be dry clay. This particular horizon also exists at University Demonstration Secondary School with a resistivity value of $2715.13 \mathrm{ohm} . \mathrm{m}$ but at a depth of $23.30 \mathrm{~m}$. At the dumpsite, the fifth layer whose depth and thickness could not be reached has a resistivity value of 677.08 ohm.m suspected to be a fresh uncontaminated water sand and occurs after a depth of $23.0 \mathrm{~m}$. This freshwater sand layer with a resistivity value of $490.40 \mathrm{ohm} . \mathrm{m}$ also occurs immediately after the dry clay horizon at the University Demonstration Primary School.

We observed that the groundwater in the second layer at the dumpsite is polluted among other things because of its high conductivity value. The breakdown of excess organic matters in waste dump does not only consume energy but also release a variety of compounds into the groundwater among them nitrate, phosphates, and sulphates and this is known as euthrophication (Carla, 2000). Older dumps generate leachate plumes which travel kilometers in more permeable environment (Moody, 1996) like in the Niger Delta. To confirm this, water samples were taken from three boreholes within the vicinity and analyzed in the laboratory. The result is presented in table 2 .

Table 2: Mean Results of Water Samples from Three Boreholes in Choba Area

\begin{tabular}{ll}
\hline \multicolumn{1}{c}{ Parameters analyzed } & \multicolumn{1}{c}{ Result } \\
\hline $\mathrm{pH}$ & 8.71 \\
$\mathrm{Conductivity}(\mathrm{NUT})$ & 60 \\
$\mathrm{Cl}(\mathrm{mg} / \mathrm{l})$ & 100.90 \\
$\mathrm{NO}_{3}^{-}(\mathrm{mg} / \mathrm{l})$ & 4.41 \\
$\mathrm{SO}_{2}^{2-}(\mathrm{mg} / \mathrm{l})$ & 13.89 \\
$\mathrm{COD}(\mathrm{mg} / \mathrm{l})$ & 15.60 \\
$\mathrm{BOD}(\mathrm{mg} / \mathrm{l})$ & 0.33 \\
$\mathrm{TSS}(\mathrm{mg} / \mathrm{l})$ & 8.283 \\
$\mathrm{TDS}(\mathrm{mg} / \mathrm{l})$ & 3218 \\
$\mathrm{Na}^{+}(\mathrm{mg} / \mathrm{l})$ & 8.30 \\
$\mathrm{Fe}^{2+}(\mathrm{mg} / \mathrm{l})$ & 2.017 \\
$\mathrm{Cu}^{2+}(\mathrm{mg} / \mathrm{l})$ & 0.319 \\
$\left.\mathrm{~Pb}^{2} \mathrm{mg} / \mathrm{l}\right)$ & 0.004 \\
$\mathrm{Zn} \mathrm{mg/l}$ & 0.372 \\
\hline $\mathrm{Cr} \mathrm{mg} / \mathrm{l}$ & 0.006 \\
\hline $\mathrm{N} . \mathrm{B} \quad \mathrm{COD}=$ Chemical oxygen Demand, BOD $=$ \\
$\mathrm{Biochemical} \mathrm{oxygen} \mathrm{demand,} \mathrm{TSS} \mathrm{=} \mathrm{Total} \mathrm{suspended} \mathrm{solid.}$ \\
The water analysis from the contaminated environment was \\
compared with the World Health Organization (WHO) standard for \\
drinking water as presented in table 3.
\end{tabular}


Table 3: Comparison of mean Result of Water Samples and Whole Standard

\begin{tabular}{lll}
\hline \multicolumn{1}{c}{ Parameters } & Results from the dumpsite & WHO standard \\
\hline $\mathrm{pH}$ & 8.71 & $7-8.5$ \\
Conductivity NUT & 60 & NIL \\
$\mathrm{Cl}(\mathrm{mg} / \mathrm{l})$ & 100.90 & $200-600$ \\
$\mathrm{NO}_{3}^{-}(\mathrm{mg} / \mathrm{l})$ & 4.41 & $50-100$ \\
$\mathrm{SO}_{4}^{2-}(\mathrm{mg} / 1)$ & 13.89 & $200-400$ \\
$\mathrm{COD}(\mathrm{mg} / \mathrm{l})$ & 15.60 & NIL \\
$\mathrm{BOD}(\mathrm{mg} / \mathrm{l})$ & 0.33 & NIL \\
$\mathrm{TSS}(\mathrm{mg} / \mathrm{l})$ & 8.282 & $500-1500$ \\
$\mathrm{TDS}(\mathrm{mg} / 1)$ & 321.8 & NIL \\
$\mathrm{Na}(\mathrm{mg} / \mathrm{l})$ & 8.30 & NIL \\
$\mathrm{Fe}^{2+}(\mathrm{mg} / \mathrm{l})$ & 2.017 & $0.300-1.0$ \\
$\mathrm{Cu}(\mathrm{mg} / \mathrm{l})$ & 0.319 & $1.00-1500$ \\
$\mathrm{~Pb}(\mathrm{mg} / \mathrm{l})$ & 0.372 & 0.1 \\
$\mathrm{Zn}(\mathrm{mg} / \mathrm{l})$ & 0.372 & $5.00-1500$ \\
\hline $\mathrm{Cr}(\mathrm{mg} / \mathrm{l})$ & 0.006 & 0.5 \\
\hline
\end{tabular}

Observation from table 3 shows that $\mathrm{pH}$ is normal but $\mathrm{NO}_{3}^{-}, \mathrm{SO}_{4}^{+}, \mathrm{Cl}^{-}, \mathrm{Cu}, \mathrm{Pb}, \mathrm{Zn}$ and $\mathrm{Cr}$ were low in concentration. $\mathrm{Fe}^{2+}$ is high which is attributed to the ferrigeneous Benin sands which contain the mineral haematite, limonite and goethite (Udom et al 1999). The conductivity is high confirming the result obtained from the geophysical sounding. Most of the boreholes drilled in Choba and it environs hardly exceeds $13 \mathrm{~m}$. From the model presented in table one it is crystal clear that any good borehole for a portable drinking water should exceed $50 \mathrm{~m}$ into the third aquiferous system or at least into the second after $25 \mathrm{~m}$. As we have multiple aquifer system in the Niger Delta, drillers will be advised to go at least for the third aquifer.

Conclusion: Solid wastes are mainly disposed off to the landfill because it is the simplest, cheapest and most cost effective method of disposing off wastes. In most low to medium income developing nations almost one hundred percent $(100 \%)$ of generated waste goes to landfill and because of this, landfill is likely to remain a relevant source of groundwater contamination in foreseeable future. Considering the nature and geology of the Niger Delta, always reclaiming and filling, and the permeability of the top formation - the Benin sand, dumpsites must be located on a geologically impermeable ground like clay. Clay being relatively impermeable to water is used when natural seals are needed such as in the cores of dams or as a barrier in landfills against seepage. Variable amount of water in trapped in clay by polar action and clay adsorption removes heavy metals from waste water.

Geophysical resistivity sounding method has enabled us detect contaminated groundwater within our environment, and we encourage all wound-beborehole owners or drillers to carry out geophysical sounding to ascertain the nature of the groundwater within his/her environment and make sure the amateur drillers get to the freshwater aquifer at the appropriate depth. If it is possible for government legislation on this matter it is beautiful. Some of the water we drink is polluted.

\section{REFERENCES}

Abdul Nassir, S.S., Loke, M.H., Lee, C.Y., Nawawi, M.N.M., (2000). Salt-water Intrusion Mapping by Geoelectrical Imaging Surveys. Geophys. Prospect 48:647-661.

Adepelumi, A.A., Ako, B.D., Ajayi, T.R., Afolabi, O., Ometoso, E.J., (2008). Delineation of saltwater intrusion into the freshwater aquifer of Lekki. Penninsula, Lagos, Nigeria. Environ Geol 56: 927-933.

Akpokodje, E.G., (1999). Principle of Applied and Environmental Geology. Paragraphic Publisher, Port Harcourt $147 \mathrm{p}$.

Avbovbo, A.A., (1978). Tertiary Lithostragraphy of the Niger Delta. AAPG, V. 62 No. 2, p. 295 300 .

Barker, R.D., (1990) Improving the quality of resistivity sounding data in landfill studies. In: Ward, S.H. (ed) Geotechnical and Environmental Geophysics. Vol. 2: Environmnetal and Groundwater. Tulsa: Society of Exploration Geophysicists $245-251$.

Carla, W., Montgomery (2000) Water Pollution, Environmnetal Geology. pg. 385 - 395 Northern Illinous University, Mc Graw Hill, New York $7^{\text {th }}$ edition.

Etu - Efetor, J.O., (1997). Summarized Geology of the Niger Delta. Fundamental of Petroleum Geology pg. 110 -130 Jeson Services, Port Harcourt. 
Helm, R.B., and Sealy, B.E., 1978. Petroleum Geology of Nigeria. A brief Review CMPN NXR -291.

Merki, Paul, 1972. Structural Geology of the Cenozioc Niger Delta in $1^{\text {st }}$ Conference of African Geology: Niger. Uni. Ibadan, Press, p.251-266.

Monie - Williams, M.E., Greenhouse, J.P., Mendes, J.M., and Ellert, N. (1990), Terrian Conductivity Mapping with topographic correction at three waste disposal site in Brazil. In Ward, S.H. (ed) Geotechnical and Environmental Geophysics. Vol. 2: Environmental and Groundwater. Tulsa: Society of Exploration Geophysicists, $41-55$.

Moody, D.W., (1996). Water Quality and Waste Management Sources and extent of groundwater contamination. North Carolina Co-operation, Extension Service Publication No. Ag - 441:1.

Murat, R.C., (1972) Stratigraphy and Paleogeography of the Cretaceous and Lower Tertiary in Southern Nigeria. In $1^{\text {st }}$ Conference on African Geology. Nigeria Uni. Ibadan Press p. 251 -266.

Reynolds, J.M., (1997). An Introduction to Applied and Environmental Geophysics. John Wiley and Sons New York p. 796.
Schneider, W.A., (1978). Generalized Regional Geology of Nigeria with Emphasis on Niger Delta and MPN offshore license Terms MPNMXR - 307 p.57 -70.

Short, R.C., and Stauble A.J., (1967). Outline of Geology in the Niger Delta, AAPG V. 51 No. 5 p. $761-779$.

Taylor, R., and Allen, A. (2001). Nature and Subject in Landfill. Impact Problem (Memorandum).

Udom G.J., and Esu, E.O., (2004) A Preliminary Assessment of the Impact of Solid Wastes on Soil and Groundwater system in part of Port Harcourt City and its Environs. Rivers State Nigeria. Global Journal of Environmental Sciences vol. 4 No. 1.

Udom G.J., Etu - Efetor J.O., and Esu E.O., (1999). Hydrogeochemical of Groundwater in part of Port Harcourt and Tai Eleme Local Government Area, Rivers State. Global Journal of Pure and Applied Science. 5; 545 - 551.

World Health Organization Standard (WHO) Guidelines for Drinking Water, FEPA (1991). 